NBER WORKING PAPER SERIES

SHOULD CENTRAL BANKS CARE ABOUT FISCAL RULES?

Eric M. Leeper

Working Paper 22800

http://www.nber.org/papers/w22800

\author{
NATIONAL BUREAU OF ECONOMIC RESEARCH \\ 1050 Massachusetts Avenue \\ Cambridge, MA 02138 \\ November 2016
}

I thank Jesper Lindé for comments. This is based on comments I made at the Sveriges Riksbank's conference "Rethinking the Central Bank's Mandate," June 2016. The views expressed herein are those of the author and do not necessarily reflect the views of the National Bureau of Economic Research.

NBER working papers are circulated for discussion and comment purposes. They have not been peer-reviewed or been subject to the review by the NBER Board of Directors that accompanies official NBER publications.

(C) 2016 by Eric M. Leeper. All rights reserved. Short sections of text, not to exceed two paragraphs, may be quoted without explicit permission provided that full credit, including () notice, is given to the source. 
Should Central Banks Care About Fiscal Rules?

Eric M. Leeper

NBER Working Paper No. 22800

November 2016

JEL No. E31,E5,E62,E63

\section{$\underline{\text { ABSTRACT }}$}

This essay aims to explain the nature of monetary and fiscal policy interactions and how those interactions could inform the fiscal rules that countries choose to follow. It makes two points: (1) monetary policy control of inflation requires appropriate fiscal backing; (2) European fiscal frameworks appear unlikely to provide the necessary fiscal backing.

Eric M. Leeper

Department of Economics

Indiana University

105 Wylie Hall

Bloomington, IN 47405

and Center for Applied Economics and Policy Research

and also NBER

eleeper@indiana.edu 


\title{
Should Central Banks Care About Fiscal Rules?*
}

\author{
Eric M. Leeper ${ }^{\dagger}$
}

\section{INTRODUCTION}

Fiscal crises spawn fiscal rules. On the heels of what may be the worst financial and fiscal crisis in Swedish history in the early 1990s, Sweden adopted sweeping fiscal reforms beginning in 1993. Although details about Swedish fiscal policy have evolved over time, the guiding principles have been enshrined in the "Swedish Fiscal Policy Framework" [Swedish Government (2011)]. Sweden has followed a net lending target, which currently is $1 / 3$ percent of GDP, and plans to aim for a "debt anchor" of 35 percent of GDP starting in 2019. ${ }^{1}$ After the Euro Area's sovereign debt crisis that began in 2009, member nations are now required to adopt medium-term budgetary frameworks [European Commission (Undated)]. Germany, whose fiscal position was sound despite a large crisis-induced run up in government debt, adopted a debt brake in 2011 that sets the maximum structural new borrowing limit at 0.35 percent of GDP [Federal Ministry of Finance (2015)].

Each of these approaches to fiscal rules focuses on ensuring that fiscal policy is "sustainable." ${ }^{2}$ Unfortunately, the fiscal rules countries are adopting seem to take "sustainability" to mean single-minded fiscal austerity. The rules appear to reflect the principle that low debt is good debt, with little consideration given to how fiscal policy needs to behave for monetary policy to successfully target inflation and the roles that safe government debt plays in the financial system.

This essay aims to explain the nature of monetary and fiscal policy interactions and how

*October 26, 2016.

${ }^{\dagger}$ Indiana University and NBER; eleeper@indiana.edu. I thank Jesper Lindé for comments. This is based on comments I made at the Sveriges Riksbank's conference "Rethinking the Central Bank's Mandate," June 2016.

${ }^{1}$ Evidently, the anchor is a target and the government must explain any deviations from target that exceed 5 percent in either direction.

2"Sustainable" is a generally ill-defined concept that gets invoked as a rationale for fiscal rules. 
those interactions could inform the fiscal rules that countries choose to follow. It makes two points:

1. Monetary policy control of inflation requires appropriate fiscal backing.

2. European fiscal frameworks appear unlikely to provide the necessary fiscal backing.

Before getting into these points, we take a step back to ask what determines the aggregate price level, and therefore inflation, in the economy. That discussion argues that a unique price level requires fiscal behavior of a certain sort. The essay then turns to explain how monetary and fiscal policy must interact in any equilibrium. This establishes point 1 . The essay then briefly discusses fiscal rules to ask if they provide the fiscal backing necessary for monetary policy to control inflation, point 2. Two appendices provide the formal background for the verbal arguments in the text.

\section{Determining the Price Level}

The aggregate price level is a relative price: it measures how much a basket of goods is worth in terms of nominal government liabilities - money plus bonds. This relative price must be determined by the interaction of supply and demand for these government liabilities.

To the private sector - the ultimate holders of government-issued paper money - demand for money and bonds depends, as it does for any asset, on expected discounted cash flows. In the case of government paper money, those cash flows are primary government surpluses - tax receipts in excess of expenditures, exclusive of the interest the government pays to holders of high-powered money and bonds. ${ }^{3}$ To the extent the liabilities also provide service flowsliquidity, collateral, and so forth-those flows also affect the liabilities' value.

This asset-pricing logic creates a direct link between the nominal objects being priced (nominal liabilities) and the "goods" (surpluses) that give them value. Critical to understanding how the price gets determined is the fact that the government - the central bank and fiscal authority jointly - controls both the nominal quantity of liabilities outstanding and the real quantity of goods that back the liabilities. By varying either the nominal supply or the real backing, the government can achieve any relative price it desires.

Appreciating that the price level is the price of goods in terms of nominal liabilities radically alters how to think about inflation. This is the essence of the fiscal theory perspective on price-level determination. ${ }^{4}$ It may be helpful to contrast this perspective with more conventional views.

\footnotetext{
${ }^{3}$ High-powered money is currency plus bank reserves. Although currency earns no interest, many countries now pay interest on reserves.

${ }^{4}$ This theory is developed formally in Leeper (1991), Sims (1994), Woodford (1995), and Cochrane (1999).
} 
Monetarists emphasize that the equilibrium price level emerges from the interplay of the supply and demand for money. Individuals seek to hold some real value of money balances to acquire goods or to hold their wealth in liquid form. The central bank supplies the nominal quantity of money, but its real value - and thus the price level - is determined by real factors like private sector wealth, which are ground out by the economy's general equilibrium. These real factors are beyond the control of policy, at least in the long run. Expectational considerations, particularly expectations of inflation, can also affect the desired level of real money balances, as Obstfeld and Rogoff (1983) show. But these expectations may also be beyond the control of policy.

By the monetarist viewpoint, government controls only the nominal object-money supply - and not the real or expectational objects that determine its value. This is why monetarist models are plagued by indeterminacies and self-fulfilling equilibria [Kareken and Wallace (1981), Obstfeld and Rogoff (1983), Sims (1994)].

New Keynesian analyses fare no better. They shift the focus away from money to the nominal interest rate, which is the instrument that most modern central banks target. Fundamental economic behavior connects real consumption demand negatively to the entire expected path of ex-ante real interest rates. In the presence of nominal rigidities, monetary policy's choice of the nominal rate can affect the real rate in the short run. Higher real rates reduce demand for goods and, therefore, the price level.

But few economists believe monetary policy can affect real interest rates forever. In fact, long-run neutrality is a central tenet of inflation targeting. As in the monetarist view, new Keynesian theory gives the government control over a nominal object, but only temporary influence over real variables. Several authors have argued that indeterminacies are ubiquitous in new Keynesian models of monetary policy [Benhabib, Schmitt-Grohé, and Uribe (2001), Cochrane (2011), Sims (2013)].

Determinacy problems with monetarist and new Keynesian perspectives stem from attempts to view inflation as a purely monetary phenomenon. Problems disappear once fiscal policy, and its control of primary surpluses, is fully integrated into the analysis. Cochrane (2011) and Sims (2013) illustrate that appropriate fiscal backing for monetary policy can eliminate self-fulfilling explosive inflation paths. Del Negro and Sims (2015) specify fiscal behavior that rules out low-inflation traps.

Perhaps monetary economists dismiss the joint monetary-fiscal message on the grounds that abstract theoretical arguments have little relevance for the practical problems that central banks now face. After all, have we ever seen a speculative hyperinflation? Maybe not. But we are all now living through extended periods of low inflation and tepid economic growth. Maybe it's time to adopt a broader perspective on inflation than money-only views 
offer.

Movement toward that broader perspective starts with understanding how monetary and fiscal policy must interact in any equilibrium. Although there are many similarities between how monetary and fiscal policy affect the economy, one distinction between the two is central: fiscal policy has taxing power; monetary policy does not. ${ }^{5}$

\section{How Monetary and Fiscal Policies Interact}

Rather than explore the pathologies of exploding inflation or chronic deflations, this discussion focuses, as do most central bank models, on relatively small fluctuations around a stable and unique steady state. The discussion is about "normal times" or even periods, like now, when inflation has been moderately below target for some period. Appendix A describes the formal model and the solution that underlies this verbal description.

Macroeconomic policies have two fundamental tasks to accomplish: determining the price level (and inflation rate) and stabilizing government debt. Of course, policies have a great many other objectives as well, but if they are not successful in achieving these two minimal tasks, they will be unable to pursue other worthy objectives.

The Riksbank, like many central banks, has a mandate to target inflation. If inflation is not determined uniquely, it means that inflation can wander around in a manner detached from the central bank's actions and goals. Clearly, an inflation-targeting central bank must ensure that inflation is unique and that it responds in predictable ways to policy actions.

Analogously, if policies do not stabilize debt, then debt can grow without limit to a point where it is impossible for the government to honors its obligations. In this situation, the government can no longer borrow and it must finance all its spending year-by-year. Inability to borrow makes fiscal policy unable to conduct countercyclical policy or to build automatic stabilizers into spending and taxes. Tax rates and spending will have to move dramatically over time with shocks that hit the economy. Those dramatic movements create inefficiencies that reduce economic well being.

Price-level determination and debt stabilization are necessary for good economic performance, so it is important to understand how monetary and fiscal policy together can achieve them. The theoretical literature finds that there are two different mixes of monetary and fiscal behavior that deliver both a determinate price level and stable debt when attention is limited to bounded equilibria, as it is in central bank models. I describe these in terms of common - and simple - specifications of policy rules: monetary policy sets the short-term

\footnotetext{
${ }^{5}$ This statement makes the distinction too stark. Modern central banks do have some taxing capacity through seigniorage revenues. But using this tax instrument will generally conflict with achieving an inflation target.
} 
nominal interest rate as a function of current inflation and fiscal policy makes tax revenues net of transfers respond to past real government debt outstanding, where both net revenues and debt are measured as ratios of GDP. These are stylized policy rules: actual policy behavior is far more complex.

\section{Regime M}

Monetary Policy: targets inflation by raising nominal interest rate more than one-for-one with inflation

Fiscal Policy: raises taxes when real government debt rises by enough to cover real debt service and to eventually retire the increase in principal

Label: Active Monetary and Passive Fiscal Policy

\section{Regime F}

Monetary Policy: adjusts nominal interest rate weakly in response to inflation to ensure that interest payments on government debt do not destabilize debt

Fiscal Policy: makes taxes unresponsive to state of government indebtedness and the price level

Label: Passive Monetary and Active Fiscal Policy

Monetary Policy: $i_{t}=\bar{i}+\alpha\left(\pi_{t}-\pi^{*}\right)+\varepsilon_{t}^{i}$

\section{Policy Rules}

Fiscal Policy: $\quad T_{t}=\bar{T}+\gamma\left(b_{t-1}-b^{*}\right)+\varepsilon_{t}^{T}$

Table 1: Two policy mixes that deliver determinate price level and stable debt. In the policy rules, $i$ is the interest-rate instrument, $\pi_{t}$ and $\pi^{*}$ are actual and target inflation, $T$ is tax revenues net of transfers as a ratio of GDP, $b_{t-1}$ and $b^{*}$ are actual and target debt-GDP levels. The $\varepsilon$ terms are exogenous changes in policy instruments.

Table 1 summarizes the combinations of monetary and fiscal policies that are consistent with a determinant equilibrium. ${ }^{6}$ Regime M produces an equilibrium that reflects the conventional assignment of the two tasks: monetary policy controls inflation and fiscal policy ensures government solvency. This is the policy mix that virtually all central bank models assume prevails.

Regime F flips the assignments, tasking fiscal policy with determining the price level and monetary policy with stabilizing debt. Clear instances of this regime have occurred

\footnotetext{
${ }^{6}$ The table refers to "taxes" as the fiscal instrument, but this should be understood more generally to be the primary surplus - revenues less expenditures net of interest payments on debt.
} 
historically: during wars, when governments borrow heavily, central banks stabilize debt by pegging the interest rate and keeping bond prices high to help finance the war; during recoveries from large financial crises - the Great Depression or the 2009 global financial crisis - central banks keep interest rates at or near their lower bound for extended periods.

\subsection{Regime M: Active Monetary/Passive Fiscal Policies}

This conventional assignment of tasks produces the conventional monetarist/new Keynesian outcomes. When the central bank tightens monetary policy by raising the short-term nominal interest rate - an increase in $\varepsilon_{t}^{i}$ in table 1 -inflation falls. But it turns out that fiscal behavior is central to generating this conventional result. A higher policy interest rate has fiscal consequences because it raises yields and debt service on government bonds. When the higher interest rate is engineered by an open-market sale of bonds, the action also raises the principal held by the private sector.

Suppose, in contrast to the passive fiscal behavior in regime M, fiscal policy were to hold taxes fixed following the monetary contraction (that is, fiscal policy sets $\gamma=0$ ). If taxes do not rise to cover the additional debt service due to higher interest rates, then the debt service will get financed by selling more nominal government bonds. In time, people will see that nominal debt is growing but taxes are not rising and they will come to expect higher inflation. That expectation will induce people to substitute out of nominal assets and into buying goods, driving up actual inflation.

We have a contradiction. Monetary policy actions geared toward reducing inflation set in train forces that raise inflation if fiscal policy does not respond appropriately. But regime $\mathrm{M}$ posits that fiscal policy will not hold taxes fixed. Higher interest rates raise real debt in two ways: through increased debt service and through a lower price level that raises the real value of nominal bonds. Passive fiscal behavior increases taxes enough to finance the interest payments and gradually retire any increase in real principal. This is the accounting explanation of passive fiscal policy.

What is the economics behind passive fiscal behavior? The contradiction arose because higher debt service raises bond holders' wealth if taxes are not expected to increase. And because the higher interest payments get rolled into increased debt issuance every period, the size of the wealth effect grows over time. Passive fiscal policy eliminates the wealth effect by following a rule that informs bond holders that their increased bond wealth will be taxed away in the future. With the wealth effect gone, the monetary policy action successfully brings inflation back to target.

Of course, since 2009 central banks have generally been trying to raise inflation, not lower it. But the reasoning that fiscal policy must eliminate monetary policy-induced wealth 
effects is perfectly symmetric. When the central bank reduces interest rates in order to raise inflation, it triggers negative wealth effects that need to be offset by lower future taxes.

At the beginning of the financial crisis, monetary and fiscal policies were complementary: central banks rapidly reduced interest rates and many governments implemented substantial fiscal stimulus packages. Those packages, though, took the form of temporary increases in spending and decreases in taxes. And when the stimulus expired, countries quickly began to consolidate fiscal policy. By 2010, the IMF's Fiscal Monitor was entitled "Fiscal Exit: From Strategy to Implementation," making clear that the time for fiscal retrenchment had arrived [International Monetary Fund (2010)].

Consider the situation in which countries like Sweden, Switzerland, Japan, and the Euro Area find themselves. Inflation has been chronically below target and policy interest rates have been pushed into negative territory after being near zero for many years. Those central banks have also engaged in sizeable asset purchases designed to drive down interest rates at the long end of the yield curve. Despite what in regime $M$ constitutes very loose monetary policy, inflation has remained stubbornly low. How can this happen? Section 4 will return to this conundrum.

Exogenous changes in fiscal policy in this regime are trivial by design. Passive fiscal behavior delivers Ricardian equivalence in simple representative agent models. Cuts in lumpsum taxes or increases in transfers are initially financed by more bond issuance. But higher real debt raises the taxes that people expect to pay in the future. Recipients of the tax cut save their increase in disposable income to pay for those future taxes. The fiscal rule in regime $\mathrm{M}$ ensures future taxes exactly offset the initial tax cut or transfers increase so there is no wealth effect and no impact on inflation. ${ }^{7}$

\subsection{Regime F: Passive Monetary/Active Fiscal Policies}

Switching policy assignments, as regime F does, dramatically alters the impacts of monetary and fiscal policies and the roles that the two policies play in determining inflation and stabilizing debt. The notions that fiscal behavior may determine the price level and monetary policy can stabilize debt may be alien to some readers, so I'll try to explain how these can happen.

The simplest examples of regime $\mathrm{F}$ policies look a lot like the policies many advanced economies adopted immediately after the financial crisis hit: monetary policy pegged the nominal interest rate and fiscal policy chose taxes and spending that created deficits designed to stimulate the economy, setting aside efforts to stabilize debt. In terms of the rules in table

\footnotetext{
${ }^{7}$ Of course, exact Ricardian equivalence is an extreme and implausible assumption. Fortunately the logic of the arguments in this essay does not rely on this assumption.
} 
1, these policies set $\alpha=0$ and $\gamma=0$. Appendix B goes through this case formally; here I focus on the economic intuition.

Imagine that the government increases transfers to the public - lower $\varepsilon_{t}^{T}$-and finances those transfers by selling new nominal government bonds. Because fiscal policy is not responding to debt and the public understands this behavior, people see that the transfers do not generate higher future taxes (or lower transfers). This makes them feel wealthier and they try to use those transfers to buy goods they can consume. Higher demand for goods raises the krona price of goods. As goods prices rise, the nominal assets people hold lose value, tempering the higher real demand. If the supply of goods in the economy is perfectly inelastic, equilibrium is restored once the price level has risen enough to eliminate the initial positive wealth effect. ${ }^{8}$

How does monetary policy behavior fit into this chain of reasoning? An essential step in the reasoning is that the price level (and inflation rate) rises sufficiently to eliminate the initial wealth effect from higher transfers. Suppose that the central bank tries to combat this inflation by sharply raising the nominal interest rate, as it does in regime M. This policy reaction triggers a very different sequence of events. Higher rates increase bondholders' interest receipts, which do not portend offsetting future taxes in regime F. People will want to convert this interest income into consumption goods, further increasing demand for goods to drive prices still higher. A hawkish central bank responds to this second round of inflation by raising interest rates still more. This sets off a cycle that puts the economy on a path along which inflation and nominal government debt explode. Loyo (1999) argues that a mix of active monetary and active fiscal policies caused Brazil's hyperinflation in the late 1980s. This is why stability in regime F requires monetary policy to respond only weakly to inflation.

Pegging the interest rates means monetary policy does not respond at all to the inflation that the original transfers increase produces. Keeping the nominal interest rate fixed prevents interest payments from destabilizing debt. In this simple economy, a one-time increase in transfers financed by nominal bonds creates a jump in the price level that keeps the real value of newly-issued debt unchanged. Pegging the interest rate permits this jump to occur.

If the central bank does not hold the interest rate fixed, instead raising it modestly with inflation, the mechanism takes on a dynamic element. A weak increase in the interest rate produces a weak increase in bondholders' interest receipts in the subsequent period. ${ }^{9}$ Higher

\footnotetext{
${ }^{8}$ Inelastic supply is a simplifying assumption that can be dispensed with at the cost of substantial complication. In the presence of nominal rigidities, goods supply becomes elastic, responding to changes in the price level. Nominal rigidities enrich, but also greatly complicate, the analysis.

${ }^{9}$ Here all government bonds are pure discount bonds that mature in one period. Bonds bought in period $t$ cost $B_{t} /\left(1+i_{t}\right)$ krona and pay $B_{t}$ krona next period. Generalizing to a full maturity structure for bonds
} 
interest income is spent on goods next period, raising the price level. Once again, this sets off a cycle, but in this case the cycle is stable and the interest income and price effects gradually dissipate.

Just as fiscal policy provided backing for monetary policy's control of inflation in regime $\mathrm{M}$, monetary policy supports fiscal policy in regime $\mathrm{F}$ by ensuring government debt is stable. In both regimes, stability comes from a passive policy authority that accommodates the actions the active authority takes.

We have established that exogenous fiscal actions have very different impacts in regime $\mathrm{F}$ than in regime $\mathrm{M}$. It turns out that monetary actions also have very different effects in the two regimes. Alert readers have probably deduced that a positive shock to the interest rate in regime $\mathrm{F}$ will eventually raise rather than lower inflation. This seemingly perverse outcome stems from precisely the wealth effects from debt service that have been a theme of this essay. Whether the higher interest rate raises, lowers, or leaves unchanged the price level on impact depends on various model details.

In regime $\mathrm{M}$, positive wealth effects from higher interest rates were eliminated by higher taxes. Those taxes are not forthcoming in regime F. By the reasoning above, higher future interest income will raise future demand and future prices. One immediate result is that "tighter" monetary policy - a higher policy interest rate - raises expected inflation in regime F.

\subsection{Summary}

In one important respect the policy effects in regime $\mathrm{F}$ require far less stringent assumptions about private behavior than do the outcomes in regime M. Central to both the monetary and fiscal impacts in regime $\mathrm{M}$ is the assumption that private agents know the policy rules that authorities obey and form expectations of future policies rationally. For example, Ricardian equivalence requires the private sector to save current tax cuts to pay for rationally expected future tax hikes. Similarly, monetary policy's control of inflation rests heavily on private agents anticipating that future taxes will eliminate the wealth effects of changes in nominal interest rates. Eusepi and Preston (2013) and Sims (2016a) show that if private behavior is purely backward-looking, equilibria always resemble those in regime F.

I trust that this exposition makes it clear that a central bank tasked with targeting inflation needs to be confident that fiscal policy will behave in a passive manner. In practice, discovering the nature of fiscal behavior can be tricky. A first step in the process of discovery is for central bank models to include fiscal details - nominal government debt, tax rates, various types of expenditures, and rules for fiscal behavior. A second step is to permit the alters the dynamics, but not the basic logic. See Cochrane (2001) or Leeper and Leith (2016). 
data to inform about the prevailing monetary-fiscal regime. I know of no central banks that have taken these steps.

\section{Fiscal Rules \& Fiscal BaCKing}

In this section I focus on two countries that have had fiscal rules for some years and take those rules seriously. By "seriously" I mean the governments actually follow the rules. My intent is not to conduct a rigorous analysis of exactly how fiscal policies in these countries have affected their inflation processes - such analysis goes well beyond this essay. Instead, I briefly describe the countries' rules and point to some merely suggestive evidence that these rules may make it difficult for the Swedish and Swiss central banks to achieve their inflation targets.

Sweden's Fiscal Policy Framework lays out the general principles that guide fiscal policy [Swedish Government (2011)]. Each government then adopts the particular rules it will follow to be consistent with the framework. Currently, Sweden aims for a $1 / 3$ percent of GDP target for net lending (the surplus inclusive of interest payments) and is now considering also imposing a 35 percent of GDP "debt anchor." This anchor is akin to a target around which debt will fluctuate within prespecified bounds. ${ }^{10}$

Since a nationwide referendum in 2001, Switzerland has followed a debt brake, which limits spending to average revenue growth over several years. If spending differs from this limit, the difference is debited or credited to an adjustment account that has to be corrected in coming years. Debt brakes have a built-in error-correction mechanism intended to restrict the size of government debt. ${ }^{11}$

The top panel of figure 1 suggests that Swedish and Swiss fiscal rules have worked to limit debt growth. In both countries, debt has steadily fallen over the past 15 years and now is about 35 percent of GDP. Remarkably - and these two countries may be the sole exceptionsdebt either continued to fall or was flat during the financial crisis. This stunning outcome is a testament to the effectiveness of fiscal rules that are followed.

But this prudent fiscal policy may have come at a cost in terms of inflation targeting. Both countries have 2 percent inflation targets that have been missed. In Switzerland, inflation has been persistently below target since the beginning of 2009. As of this writing in October 2016, CPI inflation in Sweden is about 1 percent, while it is approaching 0 percent in Switzerland.

Money-only understandings of inflation that neglect fiscal policy have a difficult time explaining why zero or negative policy interest rates that have lasted for years have failed

\footnotetext{
${ }^{10}$ Many more details are available on the Swedish Fiscal Policy Council's web page.

${ }^{11}$ See Danninger (2002) and Bodmer (2006) for additional details and analyses.
} 


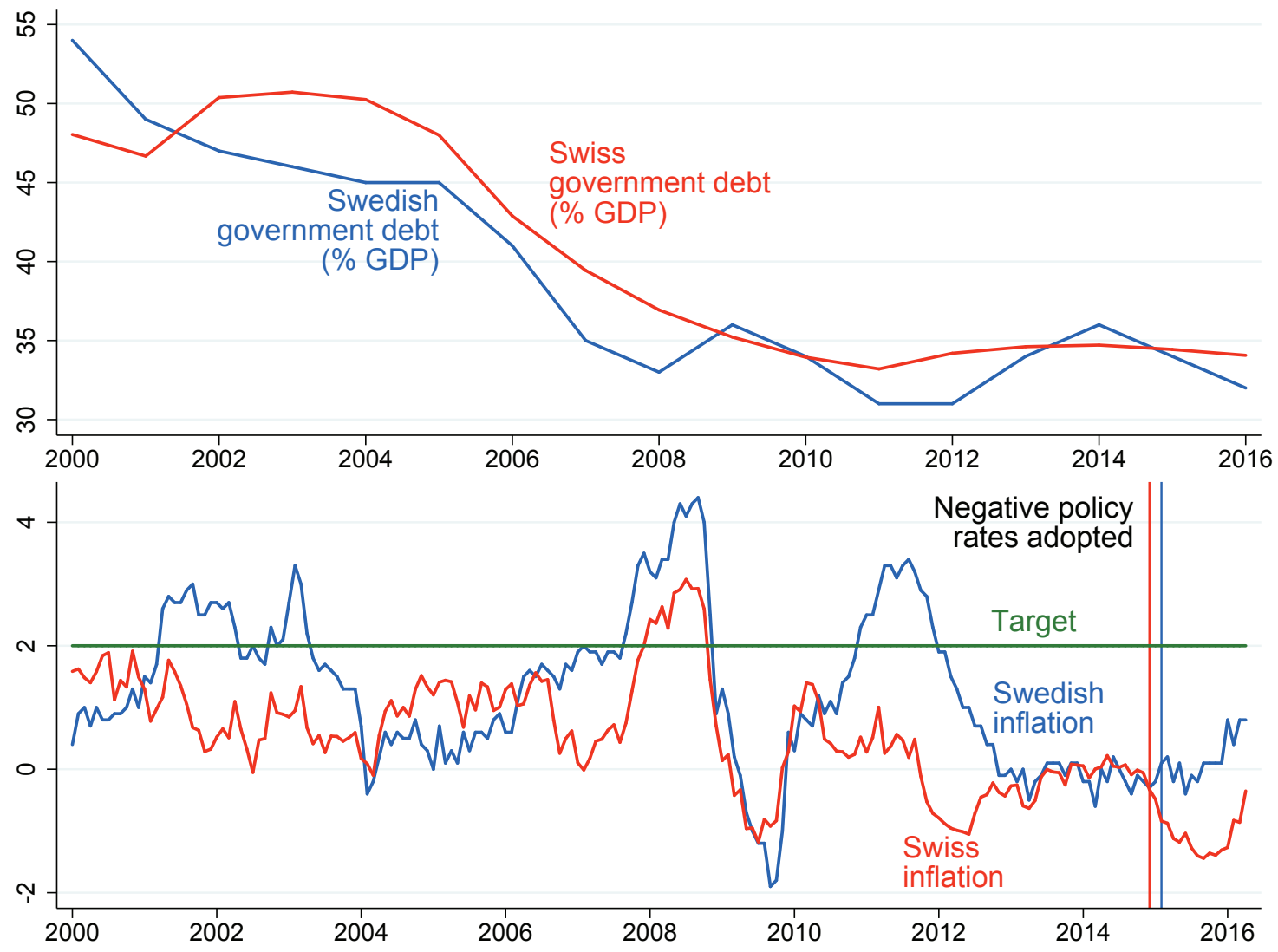

Figure 1: Debt-GDP ratio and CPI inflation rates in Sweden and Switzerland. First vertical line in bottom panel is when Swiss National Bank adopted negative policy rates and second line is when Sveriges Riksbank did.

to bring inflation up to target. ${ }^{12}$ The discussion in section 3.1 points toward one possible explanation. If the urge to reduce government debt makes fiscal policy respond asymmetrically to monetary policy - raising taxes/cutting spending when interest rates rise, but not cutting taxes/raising spending when interest rates fall - then fiscal policy is not providing the backing necessary for monetary easing to raise inflation. Whether governments in Sweden and Switzerland are implementing fiscal policy in this asymmetric manner requires careful analysis that extends well beyond the data in figure 1 .

To my knowledge, central banks are not even asking the questions that arise from conceiving of inflation as a joint monetary-fiscal phenomenon. And central bank models, as currently specified, cannot address the questions. Those models impose symmetric ruleswhen they impose any fiscal rules at all - that behave as regime M prescribes. Conditional on those rules, the models attribute below-target inflation rates in the wake of extremely

\footnotetext{
${ }^{12}$ The Swiss National Bank set the policy rate negative beginning in December 2014 and Sveriges Riksbank made the repo rate negative starting in February 2015.
} 
low monetary policy interest rates to a host of non-policy shocks - price or wage markups, preferences - or to foreign policy disturbances. The argument in this essay points away from shocks and toward systematic, asymmetric fiscal policy behavior.

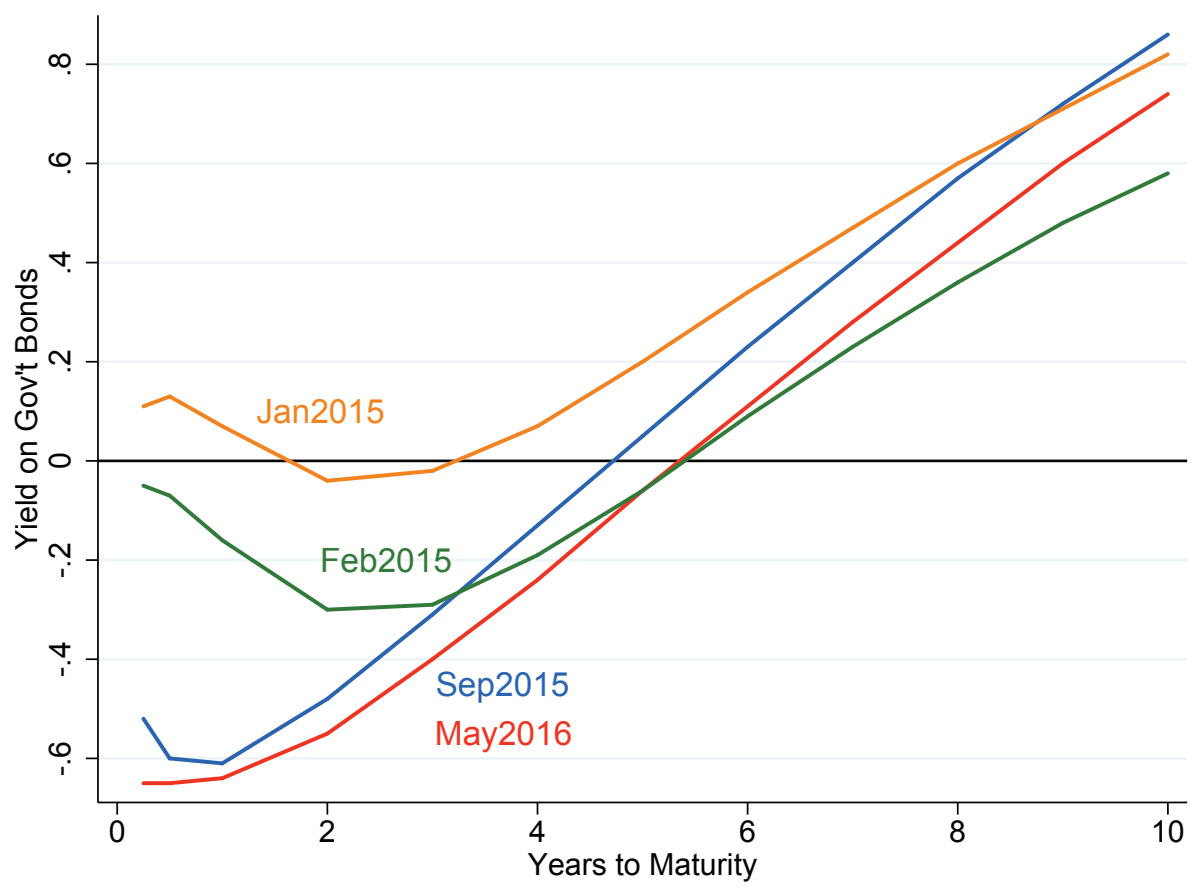

Figure 2: Yield curves for Sweden at various dates. Source: Sveriges Riksbank.

Figures 2 and 3 report evidence consistent with the view that Swedish and Swiss fiscal policies have focused strongly on debt reduction. The figures plot estimated zero-coupon government bond yield curves at various dates. In Sweden yields are negative for maturities up to five years, as figure 2 shows. Swiss yields are even more striking: negative at maturities of 10 years, as figure 3 plots.

A careful analysis would decompose these negative yields into components due to expected inflation, long-term real interest rates, and term premia. It's treacherous to read too much into these figures, but they do stimulate some questions. Is there a shortage of safe assets in these countries? Do these yields mean that inflation expectations have become untethered from the central banks' inflation targets? Or do the yields largely reflect declining real interest rates worldwide, which are beyond the policy authorities' influence?

We can infer something with confidence. The private sector is willing to pay these governments to borrow from them for periods of 5 to 10 years. But the governments have refused the private sector's generous offer. At a minimum the figures raise the question of why governments do not take up this offer and invest the proceeds in sovereign wealth funds, infrastructure, or any other investment whose return is likely to exceed the negative cost of 


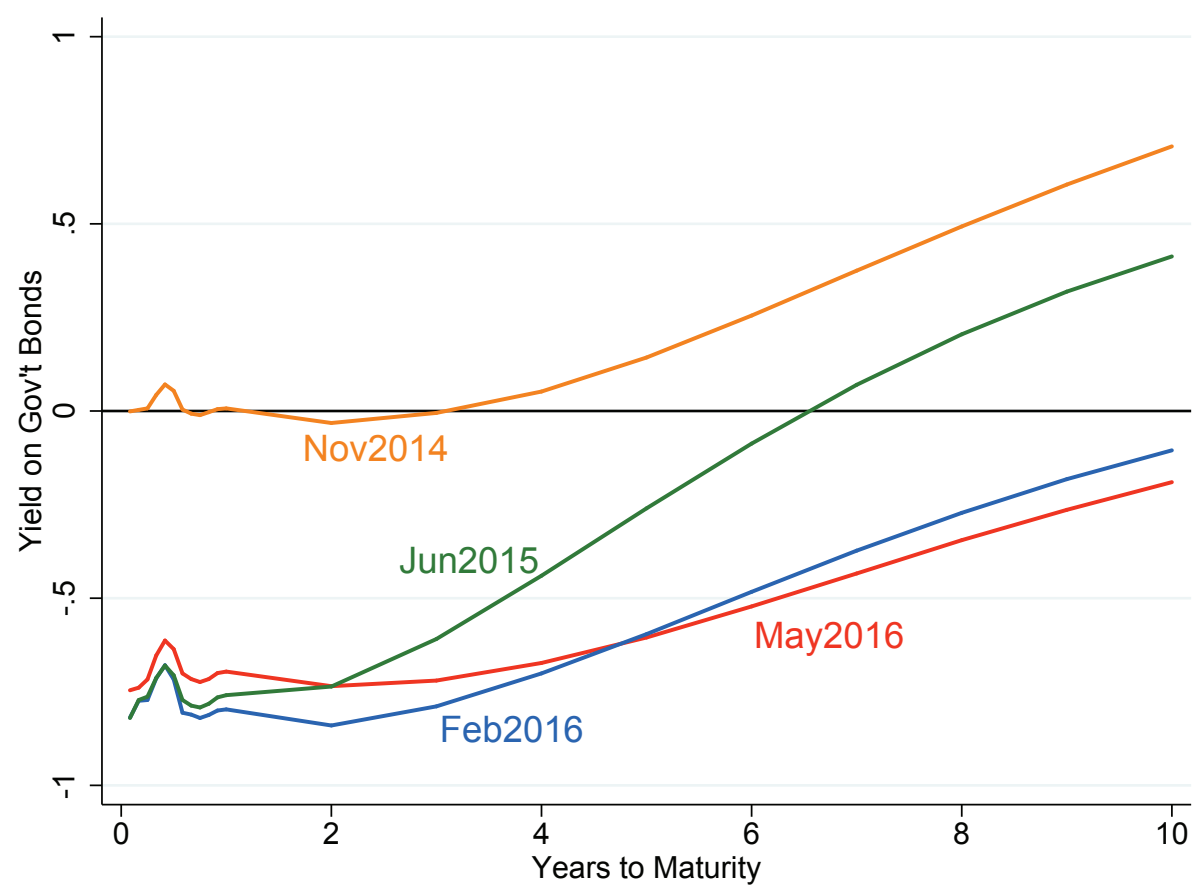

Figure 3: Yield curves for Switzerland at various dates. Source: IHS Global Insight.

borrowing.

\section{Concluding Remarks}

Research on monetary-fiscal policy interactions is not new. Friedman (1948) originally advocated a policy mix much like that in regime F. By Friedman (1960) he shifted his advocacy to something close to regime M. Importantly, both positions explicitly specified monetary and fiscal behavior. From about Friedman $(1970,1971)$ on, though, Friedman's analyses focused solely on money and monetary policy. Fiscal considerations had been pushed so deeply into the background that they didn't play any role in his views of inflation. Contemporary economists like Patinkin (1965), Tobin (1974) and Brunner and Meltzer (1974) never adopted Friedman's extreme money-only views, but their more complex approaches never gained much traction against simple monetarism.

Friedman's money-only view continue to dominate analyses of inflation and inflationtargeting frameworks in which central banks operate. Even the massive economic disruptions caused by the global financial crisis and the unprecedented and unconventional monetary policy actions of the past eight years have not shaken the belief that price-level and inflation determination can be understood without reference to fiscal policy.

Sims (2016b) offers a non-technical exposition of how bringing monetary and fiscal policy 
jointly into the picture alters one's perceptions on several pressing macroeconomic issues:

1. central bank independence;

2. large central bank balance sheets;

3. the apparent ineffectiveness of monetary policy in advanced nations in recent years;

4. providing economic stimulus when interest rates are at their lower bound.

Sims does not explicitly address the matter of whether adopted fiscal rules can conflict with the central bank's mandate to target inflation, but this is implied by much of what he writes.

Fiscal rules are designed to solve a political problem - the bias toward running excessive budget deficits - but may create an economic problem. And the cure may be worse than the disease if it undermines the ability of monetary policy to control inflation. Central banks cannot rely on fiscal authorities to work through the implications of their rules for monetary policy. That requires a level of analysis that in the realm of government, central bank economists are uniquely qualified to perform. 


\section{Appendices}

\section{A A Model of Price-Level Determination}

We examine the simplest model that can determine the economy-wide price level and inflation rate. Although simple, this model underlies the more complex models that central banks employ for policy analysis and forecasting [Christoffel, Coenen, and Warne (2008), Adolfson, Laséen, Christiano, Trabandt, and Walentin (2013), Brayton, Laubach, and Reifschneider (2014)]. To make the analytics neat, we use the model after it was been linearized around a deterministic steady state. ${ }^{13}$ This model shows that the two basic tasks of determining the price level and stabilizing the debt can be accomplished by two distinct assignments of the tasks to monetary and fiscal policy.

A single representative consumer populates the model economy. That consumer receives an endowment of goods each period and decides how much to consume and how much to save in the form of nominal government bonds. The real interest rate is constant at $1 / \beta$, where $\beta$, which is between 0 and 1 , tells how much the consumer discounts the future. We treat this discount factor as a primitive of the economy that policy cannot affect.

Because this is an economy with only a single asset - nominal bonds - the price level, $P$, is how many krona (in bonds) it takes to purchase the single consumption good, and the inverse of the price level, $1 / P$, is the goods price of one krona worth of bonds.

Four equations constitute the complete model ${ }^{14}$

$$
\begin{aligned}
\text { Fisher relation : } \quad i_{t}=E_{t} \pi_{t+1} \\
\text { Monetary policy : } \quad i_{t}=\alpha \pi_{t}+\varepsilon_{t}^{i} \\
\text { Fiscal policy : } \quad \tau_{t}=\gamma b_{t-1}+\varepsilon_{t}^{\tau} \\
\text { Government budget : } \quad b_{t-1}=\beta b_{t}-\beta i_{t}+\pi_{t}+(1-\beta) \tau_{t}
\end{aligned}
$$

The Fisher relation comes from a no-arbitrage condition and connects the nominal interest rate, $i_{t}$, to the expected inflation rate, $E_{t} \pi_{t+1}$. Monetary policy aims to target inflation by adjusting the interest rate in response to current inflation, with an exogenous shock to reflect times when policy deviates from that simple rule. Fiscal policy adjusts taxes net of transfers, $\tau_{t}$, with the level of real government debt, $b_{t}$. The exogenous shock permits fiscal choices to deviate from reactions to debt. Government purchases are zero. Government choices must satisfy a budget constraint that says any excess of existing debt payments and

\footnotetext{
${ }^{13}$ This model appears in Leeper and Li (2016).

${ }^{14}$ The deterministic steady state has zero net inflation and a surplus-debt ratio of $s / b=1-\beta$.
} 
current surpluses must be financed with new bond sales. At date $t$, the government sells pure discount nominal bonds, $B_{t}$, at price $1 /\left(1+i_{t}\right)$, which pay 1 krona in period $t+1 .^{15}$ We assume the two policy disturbances are $A R(1)$ with $A R$ coefficients $\rho_{i}$ and $\rho_{\tau}$.

This model reduces to two dynamic equations that determine how inflation and real debt evolve over time. Inflation dynamics come from combining equations (1) and (2) and debt dynamics from substituting (2) and (3) into (4) to yield

$$
\begin{aligned}
\alpha \pi_{t} & =E_{t} \pi_{t+1}-\varepsilon_{t}^{i} \\
b_{t} & =\Gamma b_{t-1}+\left(\alpha-\beta^{-1}\right) \pi_{t}+\varepsilon_{t}^{i}-\left(\beta^{-1}-1\right) \varepsilon_{t}^{\tau}
\end{aligned}
$$

where $\Gamma=\beta^{-1}-\gamma\left(\beta^{-1}-1\right)$. These two equations determine equilibrium inflation and real debt.

Before solving this model, we can learn about how monetary and fiscal policies interact by inspecting these two equations. Equation (5) might seem to suggest that inflation evolves independently of government debt, but this appearance is deceiving. Inflation at $t, \pi_{t}$, is the rate of change of the price level between period $t-1, P_{t-1}$, and $t, P_{t}$, and real debt, $b_{t}$, is nominal debt deflated by the price level, $P_{t}$. So (5) shares both $P_{t}$ and $P_{t-1}$ with (6). The price level connects monetary to fiscal policy.

Equation (6) shows that the inflation rate and the monetary policy shock, $\varepsilon_{t}^{i}$, directly affect debt dynamics. Inflation enters in two ways. First, higher inflation at $t$ reduces the value of nominal debt carried over from the previous period, which tends to reduce new debt issuance. Second, inflation affects the nominal interest rate through monetary policy behavior: higher inflation raises the nominal rate, which reduces the price of new bond sales, and requires the government to issue more bonds to support the same level of financing. Because the monetary policy disturbance also affects bond prices, it influences the evolution of debt.

To study this model, we will need to take a stand on how monetary and fiscal policy behave, as summarized by their choices of the parameters $\alpha$ and $\gamma$. We focus on finding solutions that satisfy two sensible criteria. First, inflation and debt should be stable, which is a sign that policy has been effective. Second, the solutions should be unique, otherwise we cannot say for certain what paths these variables would follow after a shock hits the economy.

Two regions of the policy parameter space deliver unique bounded equilibria [see Leeper

\footnotetext{
${ }^{15}$ This is a cashless version of the model in appendix B.
} 
(1991)]:

$$
\begin{aligned}
& |\alpha|>1,|\gamma|>1 \text { : active monetary/passive fiscal policies "Regime M" } \\
& |\alpha|<1,|\gamma|<1 \text { : passive monetary/active fiscal policies "Regime F" }
\end{aligned}
$$

\section{A.1 Regime M}

Equilibria in regime $\mathrm{M}$ are conventional monetarist/new Keynesian/Ricardian solutions. Active monetary policy makes inflation depend only on monetary policy parameters and shocks and passive fiscal policy makes debt converge gradually back to steady state following either kind of policy disturbance. The equilibrium is

$$
\begin{aligned}
\pi_{t} & =-\frac{1}{\alpha-\rho_{i}} \varepsilon_{t}^{i} \\
b_{t} & =\Gamma b_{t-1}+\left(\frac{\beta^{-1}-\rho_{i}}{\alpha-\rho_{i}}\right) \varepsilon_{t}^{i}-\left(\beta^{-1}-1\right) \varepsilon_{t}^{S} \\
\tau_{t} & =\gamma b_{t-1}+\varepsilon_{t}^{\tau}
\end{aligned}
$$

where $\Gamma \equiv \beta^{-1}-\gamma\left(\beta^{-1}-1\right)<1$.

\section{A.2 Regime $\mathrm{F}$}

For this regime, we consider the case of exogenous surpluses, $\gamma=0$, which is an analytically simple case of active fiscal policy. Inflation now depends on the fiscal disturbance and the state of government debt, while monetary policy acts to stabilize the real value of debt. This equilibrium is

$$
\begin{aligned}
& \pi_{t}=b_{t-1}-\frac{1-\beta}{1-\beta \rho_{\tau}} \varepsilon_{t}^{\tau} \\
& b_{t}=\alpha b_{t-1}+\varepsilon_{t}^{i}+\left(\frac{(1-\beta)\left(\rho_{\tau}-\alpha\right)}{1-\beta \rho_{\tau}}\right) \varepsilon_{t}^{\tau} \\
& \tau_{t}=\varepsilon_{t}^{\tau}
\end{aligned}
$$

where we take $\alpha \in[0,1)$ because negative responses of the interest rate to inflation, although theoretically possible, make little economic sense.

Notice that government debt is stable in both regimes. In regime M, the fiscal choice of $\gamma$ ensures stability and determines how rapidly debt returns to steady state. In regime F, the monetary choice of $\alpha$ does the job: as (11) reveals, $\alpha$ determines the speed of adjustment of debt toward steady state. In fact, if monetary policy were active, $\alpha>1$, debt would grow 
without bound. A weak response of monetary policy to inflation - a setting of $\alpha$ between 0 and 1 - is necessary for debt to be stable.

Another important difference between regimes is the equilibrium inflation process. In regime $\mathrm{M}$, as (7)-(9) make clear, inflation is decoupled from the joint $\left(s_{t}, b_{t-1}\right)$ process, an implication of Ricardian equivalence. In regime F, although the surplus evolves autonomously, it feeds directly into inflation and $b_{t-1}$ affects $\pi_{t}$ through a breakdown of Ricardian equivalence. In regime F, nominal debt expansions raise nominal wealth and nominal spending, raising the price level to ensure that in equilibrium there is no change in real wealth. ${ }^{16}$

\section{B The Fiscal Theory Mechanism}

We posit a permanent income theory of consumption in which a representative household makes a consumption-saving decision. The household receives an endowment $y_{t}$, pays lumpsum taxes net of transfers $\tau_{t}$, and saves in the form of nominal assets, money $M_{t}$, which earns no interest, and government bonds $B_{t}$, which sell at price $1 /\left(1+i_{t}\right)$. The household takes prices and initial nominal assets, $M_{-1}$ and $B_{-1}$, as given when it chooses sequences $c_{t}, M_{t}, B_{t}$ to maximize

$$
E_{0} \sum_{t=0}^{\infty} \beta^{t}\left[u\left(c_{t}\right)+v\left(M_{t} / P_{t}\right)\right], \quad 0<\beta<1
$$

where $u$ and $v$ are strictly increasing, strictly concave, and differentiable functions, $M_{t} / P_{t}$ is real money balances, and $E_{0}$ is the expectations operator conditional on inflation at time 0 , subject to

$$
c_{t}+\frac{M_{t}}{P_{t}}+\frac{1}{1+i_{t}} \frac{B_{t}}{P_{t}}=y_{t}-\tau_{t}+\frac{M_{t-1}+B_{t-1}}{P_{t}}
$$

Let $A_{t} \equiv M_{t-1}+B_{t-1}$ denote total nominal assets and $q_{t, t+1}$ denote the one-period real stochastic discount factor for the household, where

$$
q_{t, t+1}=\beta E_{t} \frac{u^{\prime}\left(c_{t+1}\right)}{u^{\prime}\left(c_{t}\right)}
$$

The household's intertemporal budget constraint in period 0 is

$$
E_{0} \sum_{t=0}^{\infty} q_{t}\left[c_{t}+\frac{i_{t}}{1+i_{t}} m_{t}\right]=\frac{A_{0}}{P_{0}}+E_{0} \sum_{t=0}^{\infty} q_{t}\left[y_{t}-\tau_{t}\right]
$$

where $q_{t}$ is the stochastic discount factor for computing the real value in period 0 of a unit

\footnotetext{
${ }^{16}$ See Leeper and Leith (2016) and appendix B for details.
} 
of consumption goods in period $t$, so $q_{0}=1$, and $m_{t} \equiv M_{t} / P_{t}$ is real money balances. Expression (16) uses the limiting condition $\lim _{t \rightarrow \infty} E_{0}\left[q_{t} A_{t} / P_{t}\right]=0$.

The first-order condition for money implies

$$
\frac{v^{\prime}\left(m_{t}\right)}{u^{\prime}\left(c_{t}\right)}=\frac{1}{1+i_{t}}
$$

which permits us to write the liquidity preference schedule as $m_{t}=L\left(i_{t}, c_{t}\right)$.

If we specialize the model by setting government purchases of goods to be identically zero, then goods market clearing is $c_{t}=y_{t}$ for all $t \geq 0$. Imposing goods and money market clearing on (16) leads to an expression that links the real value of initial government liabilities to their real backing, seigniorage revenues and net taxes.

$$
\frac{A_{0}}{P_{0}}=E_{0} \sum_{t=0}^{\infty} q_{t}\left[\frac{i_{t}}{1+i_{t}} L\left(i_{t}, y_{t}\right)+\tau_{t}\right]
$$

This expression may be further simplified by assuming the endowment process implies $y_{t} \equiv \bar{y}$, so that $q_{t}=\beta^{t}$. If output is constant, liquidity preference simplifies to $L\left(i_{t}, \bar{y}\right)$, and (18) becomes

$$
\frac{A_{0}}{P_{0}}=E_{0} \sum_{t=0}^{\infty} \beta^{t}\left[\frac{i_{t}}{1+i_{t}} L\left(i_{t}, \bar{y}\right)+\tau_{t}\right]
$$

Policy chooses sequences $\left\{i_{t}, \tau_{t}\right\}$. To illustrate how the fiscal theory operates, we posit the policy rules

$$
\begin{aligned}
i_{t} & =\bar{i} \\
\tau_{t} & =\bar{\tau}+\varepsilon_{t}
\end{aligned}
$$

where $E_{t} \varepsilon_{t+j}=0$ for $j>0$.

Notice that pegging the nominal interest rate pegs expected inflation since $1 /\left(1+i_{t}\right)=$ $\beta E_{t}\left[1 /\left(1+\pi_{t+1}\right)\right]$ Assume $\bar{i}$ is chosen to ensure $\bar{\pi}=0$. This and the rule for setting net taxes collapse (19) to

$$
\frac{A_{0}}{P_{0}}=L(\bar{i}, \bar{y})+\tau_{0}+\frac{\beta}{1-\beta} \bar{\tau}
$$

The real value of initial government liabilities is determined by seigniorage, summarized by $L(\bar{i}, \bar{y})$, and by current net taxes, $\tau_{0}$, and the present value of future net taxes.

Consider an increase in transfers or decrease in taxes at time 0 -lower $\tau_{0}$. Equilibrium condition (22) says that this reduced backing for liabilities must reduce their value by increasing the price level, $P_{0}$ (because initial nominal assets, $A_{0}$ are given at time 0 , and the 
tax rule, (21), implies that a change in current taxes carries no predictions about future taxes).

But the equilibrium condition masks the economic mechanisms. Those mechanisms are made clear from the household's intertemporal budget constraint, (16). Adjustment to equilibrium after a tax cut - a decline in $\tau_{0}$-involves two offsetting wealth effects. The tax cut reduces the government's holdings of goods and raises the households'. Households feel wealthier and try to spend that tax cut on consumption goods. Because the supply of goods is fixed, the household's increased demand drives up the price of goods, $P_{0}$. As the price level rises, the real value of household financial wealth, $A_{0} / P_{0}$, falls. This negative wealth effect must be sufficient to eliminate the excess demand for goods so that the household is content to consumer its endowment, $c_{t}=\bar{y}$. 


\section{REFERENCES}

Adolfson, M., S. Laséen, L. Christiano, M. Trabandt, and K. Walentin (2013): "Ramses II-Model Description," Sveriges Riksbank Occasional Paper No. 12, February.

Benhabib, J., S. Schmitt-Grohé, And M. Uribe (2001): "The Perils of Taylor Rules," Journal of Economic Theory, 96(1-2), 40-69.

Bodmer, F. (2006): "The Swiss Debt Brake: How it Works and What Can Go Wrong," Schweizerische Zeitschrift für Volkswirtschaft und Statistik, 142(3), 307-330.

Brayton, F., T. LAUbach, And D. Reifschneider (2014): "The FRB/US Model: A Tool for Macroeconomic Policy Analysis," https://www.federalreserve.gov/econresdata/notes/feds-notes/2014/a-tool-for -macroeconomic-policy-analysis.html, April.

Brunner, K., And A. H. Meltzer (1974): "Friedman's Monetary Theory," in Milton Friedman's Monetary Framework, ed. by R. J. Gordon, pp. 63-76. University of Chicago Press, Chicago.

Christoffel, K., G. Coenen, and A. Warne (2008): "The New Area-Wide Model of the Euro Area: A Micro-Founded Open-Economy Model for Forecasting and Policy Analysis," ECB Working Paper No. 944, October.

Cochrane, J. H. (1999): "A Frictionless View of U.S. Inflation," in NBER Macroeconomics Annual 1998, ed. by B. S. Bernanke, and J. J. Rotemberg, vol. 13, pp. 323-384. MIT Press, Cambridge, MA.

- (2001): "Long Term Debt and Optimal Policy in the Fiscal Theory of the Price Level," Econometrica, 69(1), 69-116.

(2011): "Determinacy and Identification with Taylor Rules," Journal of Political Economy, 119(3), 565-615.

Danninger, S. (2002): "A New Rule: "The Swiss Debt Brake"," IMF Working Paper $\mathrm{WP} / 02 / 18$, January.

Del Negro, M., And C. A. Sims (2015): "When Does a Central Bank's Balance Sheet Require Fiscal Support?," in Monetary Policy: An Unprecedented Predicament, ed. by M. Goodfriend, and S. E. Zin, vol. 73 of Carnegie-Rochester-NYU Conference Series on Public Policy, pp. 1-19. Amsterdam. 
European Commission (Undated): "Medium Term Budgetary Objectives," http://ec.europa.eu/economy_finance/economic_governance/sgp/preventive_arm /index_en.htm, accessed 19 October 2016.

Eusepi, S., And B. Preston (2013): "Fiscal Foundations of Inflation: Imperfect Knowledge," Manuscript, Monash University, October.

Federal Ministry of Finance (2015): "Germany's Federal Debt Brake," Public Relations Division, March.

Friedman, M. (1948): "A Monetary and Fiscal Framework for Economic Stability," American Economic Review, 38(2), 245-264.

— (1960): A Program for Monetary Stability. Fordham University Press, New York.

- (1970): "A Theoretical Framework for Monetary Analysis," Journal of Political Economy, 78(2), 193-238.

(1971): “A Monetary Theory of Nominal Income," Journal of Political Economy, $79(2), 232-337$.

International Monetary Fund (2010): Fiscal Monitor-Fiscal Exit: From Strategy to Implementation. IMF, Washington, D.C., November.

Kareken, J., And N. Wallace (1981): "On the Indeterminacy of Equilibrium Exchange Rates," Quarterly Journal of Economics, 96(2), 207-222.

Leeper, E. M. (1991): "Equilibria Under 'Active' and 'Passive' Monetary and Fiscal Policies," Journal of Monetary Economics, 27(1), 129-147.

LeEPer, E. M., And C. Leith (2016): "Understanding Inflation as a Joint Monetary-Fiscal Phenomenon," in forthcoming in Handbook of Macroeconomics, ed. by J. B. Taylor, and H. Uhlig, vol. 2. Elsevier Press, Amsterdam, NBER Working Paper No. 21867, January.

LeEper, E. M., AND B. Li (2016): "Surplus-Debt Regressions," Economics Letters, forthcoming.

Loyo, E. (1999): "Tight Money Paradox on the Loose: A Fiscalist Hyperinflation," Manuscript, Harvard University.

Obstaeld, M., and K. Rogoff (1983): "Speculative Hyperinflations in Maximizing Models: Can We Rule Them Out?," Journal of Political Economy, 91(4), 675-687. 
Patinkin, D. (1965): Money, Interest and Prices. Harper \& Row, New York, 2nd edn.

Sims, C. A. (1994): "A Simple Model for Study of the Determination of the Price Level and the Interaction of Monetary and Fiscal Policy," Economic Theory, 4(3), 381-399.

— (2013): "Paper Money," American Economic Review, 103(2), 563-584.

— (2016a): "Active Fiscal, Passive Money Equilibrium in a Purely Backward-Looking Model," Manuscript, Princeton University, May.

— (2016b): "Fiscal Policy, Monetary Policy and Central Bank Independence," in forthcoming in Designing Resilient Monetary Policy Frameworks for the Future. Federal Reserve Bank of Kansas City Economic Conference Proceedings, 2016 Jackson Hole Symposium.

Swedish Government (2011): The Swedish Fiscal Policy Framework. Regeringskansliet, Stockholm.

Tobin, J. (1974): "Friedman's Theoretical Framework," in Milton Friedman's Monetary Framework, ed. by R. J. Gordon, pp. 77-89. University of Chicago Press, Chicago.

Woodford, M. (1995): "Price-Level Determinacy Without Control of a Monetary Aggregate," Carnegie-Rochester Conference Series on Public Policy, 43, 1-46. 